\title{
CHANGES IN STRUCTURE OF RED PEPPER (CAPSICUM ANNUUM L.) SEEDLINGS SHOOTS UNDER ALUMINUM STRESS CONDITIONS
}

\author{
Agata Konarska \\ Departament of Botany, Agricultural Academy, ul. Akademicka 15, 20950 Lublin \\ agata.konarska@ar.lublin.pl
}

Received: 20.12.2006

\begin{abstract}
S u m m a ry
The seedlings of the red pepper (Capsicum annuum L.) cv. Trapez grown in water culture for a period of 14 days with $\mathrm{Al}$ $\left(0,10,20\right.$ and $\left.40 \mathrm{mg} \cdot \mathrm{dm}^{3} \mathrm{AlCl}_{3} \cdot 6 \mathrm{H}_{2} \mathrm{O}\right)$. Some morphological and anatomical features of red pepper shoots were analyzed. Reduc tion in height and diameter of stems as well as decrease in fresh mass of shoots were observed after Al treatment. In the hypocotyl the thickness of cortex parenchyma layer and the size of their cells were reduced. The aluminum treatment resulted in the increased in thickness of the epidermis outer cell wall. Under Al stress in the cotrex and the central cylinder parenchyma cells were present numerous enlarge plastids which contained large grains of starch and dark little bodies which were possible aluminum deposits. They weren`t observed in control seedlings.
\end{abstract}

Key words: toxicity of aluminum, red pepper, hypocotyl, structure

\section{INTRODUCTION}

The toxicity of aluminum is a factor which is commonly recognised as a factor limiting plant growth and yielding. The excess of mobile forms of this metal in the substratum affects especially underground organs of the plant, mainly roots, by inhibiting their elongation growth, causing numerous deformations and damages, as well as the limitation of water intake (Bennet and Steward, 1999; Budikova and Mistrik, 1999; Konarska, 2005). With a large concentration of aluminium ions, a reduced weight of above-ground organs: stems, leaves, flowers and seeds, was found in many plant species. However, typical symptoms of aluminium toxicity were not always noticeable on these organs (Oleksyn et al., 1996; Mangabeira et al., 1999). Most researchers are of opinion that changes observed in such cases correspond to nutrient and water deficiency symptoms which may accompany the excess of aluminium in the substratum (J anhunen et al., 1995;
Rufyikiri et al., 2001). In spite of the fact that most toxic ions of this metal taken in by the plant are immobilised in roots (B orowski, 1999; Lidon et al., 1999), a part of them can migrate to the above-ground portion in particularly sensitive or aluminium-loving plants. Aluminium deposits are then observed in leaves and accumulated in their peripheral portions, i.e. in cell walls of the upper epidermis, in particular in the cuticle layer or in the walls of palisade parenchyma cells (Garrec and Renard, 1996; Shen and Ma, 2001).

Earlier studies on the effect of aluminium on the root system of several plant species demonstrated that red pepper is a taxon very sensitive to the toxicity of this metal (Konarska, 2004). Results presented in this paper are a continuation of investigations related to this topic, and they aim to determine morphological and anatomical changes in the structure of stems of red pepper seedlings, induced by the effect of the excess of aluminium ions.

\section{MATERIAL AND MATHODS}

Red pepper (Capsicum annuum L.) seedlings were cultivated in $4 \mathrm{dm}^{3}$ plastic containers which were filled with modified Knop's medium Brauner and Bun$\mathrm{katsh} . \mathrm{AlCl}_{3} \cdot 6 \mathrm{H}_{2} \mathrm{O}$ was additionally introduced into the medium in the following concentrations: 0 (control), 10 , 20 and $40 \mathrm{mg} \mathrm{dm}^{-3}$ of the medium, what corresponds to 0 ; $1.1 ; 2.2$ and $4.5 \mathrm{mg} \cdot \mathrm{dm}^{-3}$ of pure aluminium. The $\mathrm{pH}$ of the solutions was set to 4.3 by using $0.1 \mathrm{M} \mathrm{HCl}$ or $0.1 \mathrm{M}$ $\mathrm{NaOH}$. The disinfected pepper seeds germinated on wet tissue in Petri dishes. After four days from the germination, the seedlings were transferred to water cultures. 30 plants were tested in each object. During the experiment, the medium was aired and its depletion was supplemented, and after a week it was exchanged. The experiment was conducted in three replicates and completed after 14 days. Then, the total length of shoots, the length of the 
hypo- and epicotyl were measured, and above-ground portions of the plant were weighed in order to determine the average fresh weight of these organs for one seedling.

For observations of the structure of the hypocotyl surface and anatomical examinations, middle portions of the hypocotyl of the stem, about $10 \mathrm{~mm}$ long, were sampled. From the material sampled, semi-permanent slides were prepared in glycerol-gelatine, as well as permanent semi-thin slides with $0.5 \mu \mathrm{m}$-thick sections which were stained with $1 \%$ methylene blue with $1 \%$ azur II in a $1 \%$ water solution of sodium tetraborate. Observations and figss were made in a Jenaval Contrast microscope. The diameter of the hypocotyl was then measured and measurements of the width of layers of particular tissues of this organ were made, as well as the thickness of external walls in the epidermis cells was determined. In addition, the number and size (length and width) of chloroplasts occurring in the first and fourth layer of the parenchyma of primary cortex of the hypocotyl and the number and size of leucoplasts in the endodermis were analysed. Measurement results obtained were subjected to statistical analysis. A variance analysis was performed for the complete randomization scheme (single classification) and the least significant difference for pairs of mean values (LSD) was calculated.

To perform the examination by using scanning electron microscopy, the samples taken were fixed in $2 \%$ glutar aldehyde with $2.5 \%$ paraformaldehyde in $0.075 \mathrm{M}$ phosphate buffer with the $\mathrm{pH}$ of 6.8 for 12 hours at $4^{\circ} \mathrm{C}$. Next, the material was twice washed with the buffer for 15 seconds at room temperature and with distilled water also for 15 seconds. The next stage was the dehydration of the sections in 2.2-dimethoxypropane acidified with $\mathrm{HCl}$ in accordance with Miller's and Jacks' method (1975). The dehydrated material was dried at critical point in liquid $\mathrm{CO}_{2}$ and coated with gold by using the CS100 Sputter Coater. Observations of the structure of the hypocotyl surface were made by using a BS -300 Tesla microscope.

\section{RESULTS}

The fourteen-day control pepper seedlings cultivated in water cultures developed stems with the average length of $3.83 \mathrm{~cm}$, of which the hypocotyl accounted for over $70 \%$ (Tab. 1). With the increased concentration of aluminium, the height of the plants was reduced from $28.7 \%$ up to $38.9 \%$, what was accompanied by the shortening of the length of both the hypocotyl and, to a larger degree, the epicotyl. $\mathrm{AlCl}_{3}$ doses applied also reduced drastically the average fresh weight of pepper shoots (Tab. 1).

Epidermis cells of the hypocotyl of pepper from the control object observed in SEM were of rectangular shape and they were elongated parallel to the vertical axis of the organ. On their surface, the presence of numerous glandular trichomes was found (Figs. 1,2), as well as non- glandular trichomes, and rarely occurring open stomata (Figs. 3, 4). The surface of the epidermis cells covering the hypocotyl was characterised by cuticular sculpture in the form of striae running in different directions, most frequently perpendicular to the long axis of these cells (Figs 3). In the presence of the toxicant, the hypocotyls with the reduced diameter were characterised by epidermis with a wrinkled and corrugated external cell wall (Fig 4). Elongated folds occurred on the surface of the cells in the plants treated with aluminium (Fig. 4). The glandular trichomes, both in the control plant and in the presence of aluminium, had various heights. They were composed of a 1- or 2-celled base and a spherical or oval several-celled head (Figs. 5, 7). The non-glandular trichomes were pestle-shaped. They were built of several cells arranged in tiers (Figs. 6, 8). Some of them were characterised by furrowed cuticle ornamentation (Fig. 8). In the observations made, no changes under the influence of aluminium were found in the structure of the stomata or trichomes, though the trichomes were usually shorter in the presence of the toxicant.

Light microscopy observations show that under the influence of aluminium the diameter of the hypocotyl of the pepper seedlings was reduced, in

Table 1

The influence of aluminum on stem height and fresh mass of red pepper shoot after 14 days of the experiment. An asterix indicates a statistically significant difference from the control $\left(0 \mathrm{mg} \cdot \mathrm{dm}^{3} \mathrm{AlCl}_{3}\right)$.

\begin{tabular}{|c|c|c|c|c|c|c|}
\hline \multirow{2}{*}{\multicolumn{2}{|c|}{ Investigated feature }} & \multicolumn{4}{|c|}{ Level of $\mathrm{AlCl}_{3}\left(\mathrm{mg} \cdot \mathrm{dm}^{3}\right)$} & \multirow{3}{*}{$\begin{array}{l}\text { LSD } \\
\text { P } 0.05\end{array}$} \\
\hline & & 0 & 10 & 20 & 40 & \\
\hline \multirow{3}{*}{ The stem height $(\mathrm{cm})$} & Epicotyl $+1^{\text {st }}$ internode & 1.09 & 0.56 & 0.53 & 0.50 & \\
\hline & Hypocotyl & 2.74 & $2.23 *$ & $1.81^{*}$ & $1.84^{*}$ & 0.30 \\
\hline & Total & 3.83 & $2.79 *$ & $2.34 *$ & $2.34 *$ & $0.40^{*}$ \\
\hline \multicolumn{2}{|c|}{ The shoot fresh mass (g) } & 0.63 & $0.24 *$ & $0.17 *$ & $0.17 *$ & 0.25 \\
\hline
\end{tabular}



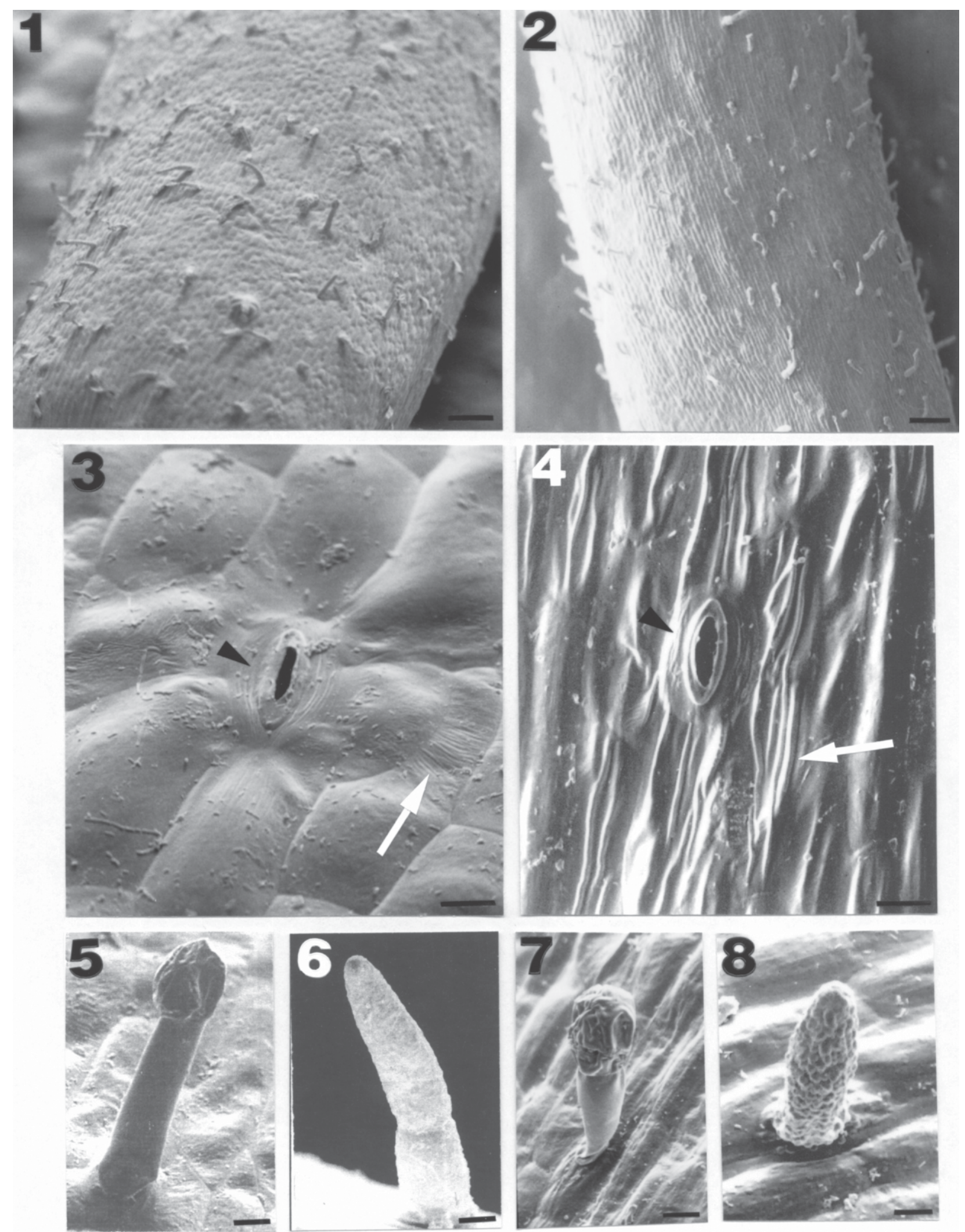

Figs. 1 8. Surface of the red pepper hypocotyl epidermis with stomata (arrow heads) (figs. 3, 4) and grandular (figs. 5, 7) and nongrandular trichomes (figs 6, 8) after 14 days treatment different levels of aluminum; 14 control, $58 \quad 40 \mathrm{mg} \cdot \mathrm{dm}^{3}$ $\mathrm{AlCl}_{3}$. Arrows show striated cuticle (fig. 3) and pleated cuticle after Al treatment (fig. 4). Bars $100 \mu \mathrm{m}$ (figs. 1, 2), bars $10 \mu \mathrm{m}$ (figs. 3 8). 

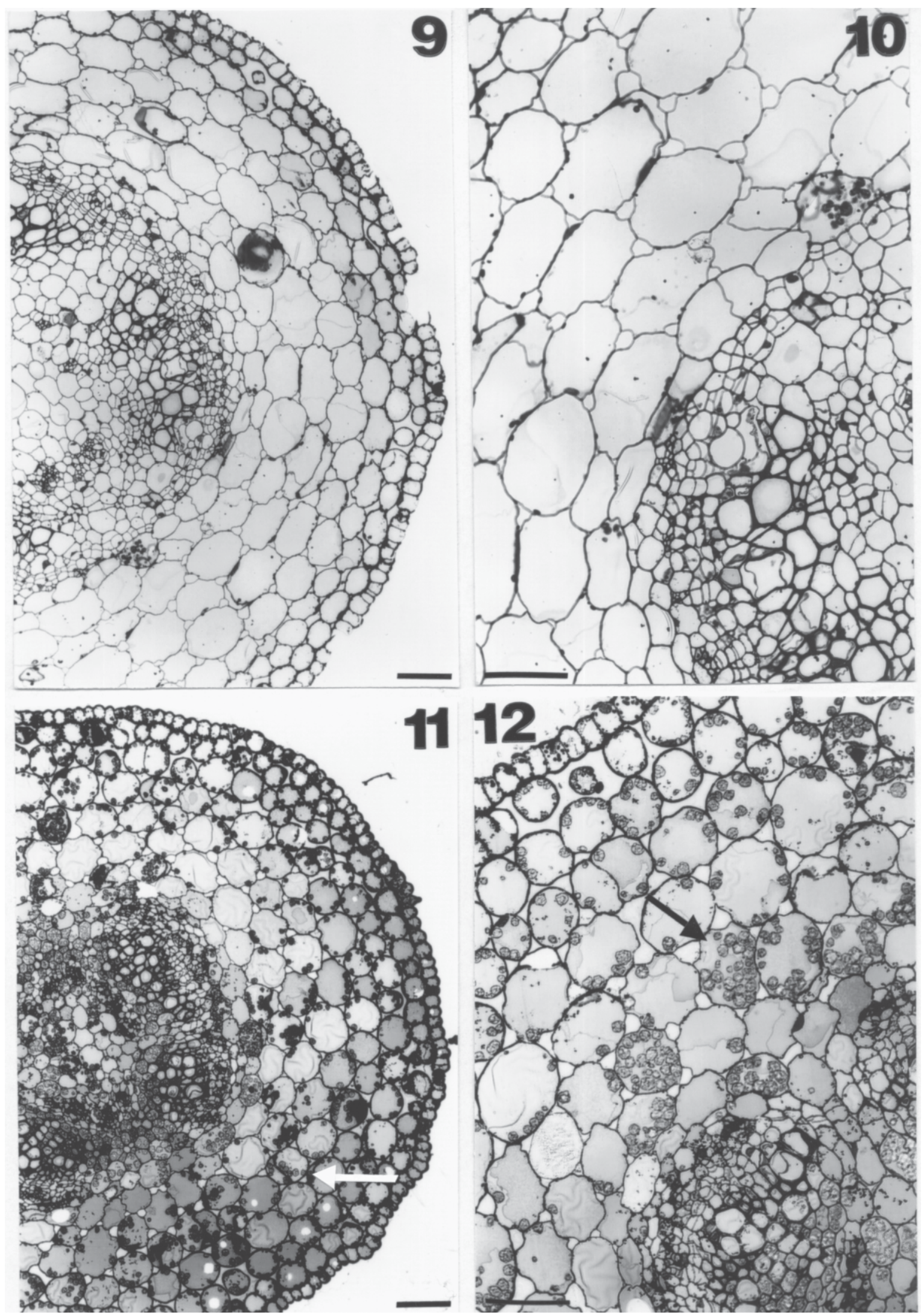

Figs. 9 12. Transverse sections of the hypocotyl of 14 days old red pepper; 9, 10 control, 11, 12 after treatment $40 \mathrm{mg} \cdot \mathrm{dm}^{3} \mathrm{AlCl}_{3}$ visible the hypocotyl diameter decreased and the size cells too. Note enlarge plastids in many cells of hypocotyl (arrows). Bars $100 \mu \mathrm{m}$. 

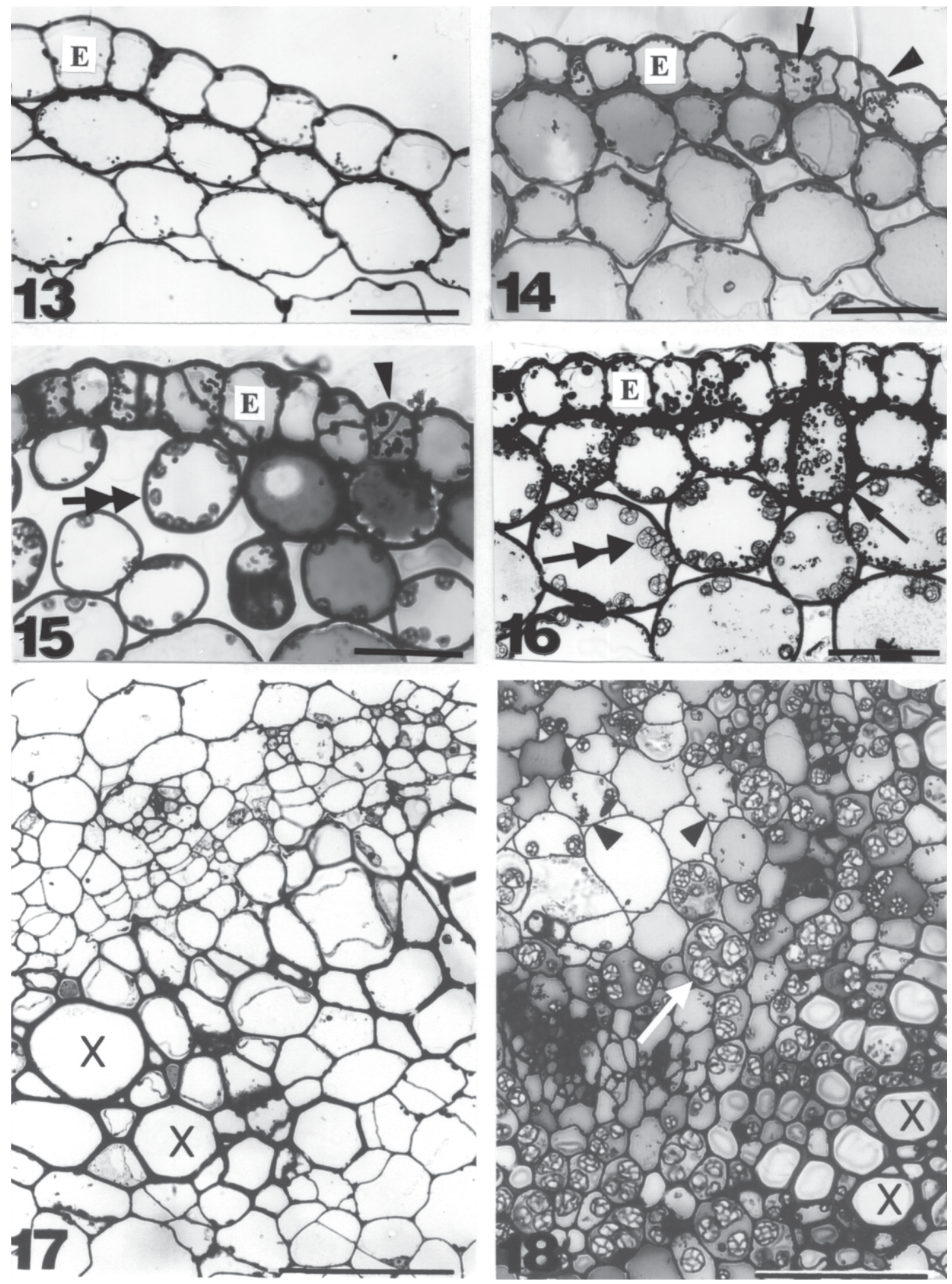

Figs. 13 16. Transverse sections of the hypocotyl of 14 days old red pepper treatment different levels of aluminum $(0,10,20,40$ $\mathrm{mg} \cdot \mathrm{dm}^{3} \mathrm{AlCl}_{3}$ ). After $\mathrm{Al}$ treatment visible untypical epidermis cell division (arrow heads) and thickening of the epidermis outer cell wall. Note numerous enlarge plastids in the parenchyma cells (double arrows) and dark spherical bodies in the parenchyma and epidermis cells (arrows). Bars $50 \mu \mathrm{m}$.

Figs. 17, 18. Transverse sections of the hypocotyl of 14 days old red pepper. 17 control, 18 after treatment $40 \mathrm{mg} \cdot \mathrm{dm}^{3} \mathrm{AlCl}_{3}$ visible xylem vessels $(\mathrm{X})$ with decrease diameter and numerous enlarge plastids in the central cylinder cells arrow as soon as dark little bodies probably being deposits of aluminum (arrow heads). Bars $50 \mu \mathrm{m}$. 
proportion to the applied doses of the toxicant. It related both to primary cortex and, to a larger degree, the central cylinder (Tab. 2, Figs. 9, 11), what was caused by a substantial reduction in the size of cells composing these strata (Figs. 10,12). No changes were observed in the height of epidermis cells of the hypocotyl under the influence of aluminium, but its influence was noted in the increased thickness of the external wall of these cells by $28 \%$ at $20 \mathrm{mg} \cdot \mathrm{dm}^{-3} \mathrm{AlCl}_{3}$ and almost by $35 \%$ at 40 $\mathrm{mg} \cdot \mathrm{dm}^{-3} \mathrm{AlCl}_{3}$, compared to the control plants (Tab. 2). In addition, at such concentrations some epidermis cells developed as a result of non-typical divisions (Figs. 14,

Table 2

The influence of aluminum on hypocotyl anatomical parameters after 14 days of the experiment. An asterix indicates a statistically significant difference from the control $\left(0 \mathrm{mg} \cdot \mathrm{dm}^{3} \mathrm{AlCl}_{3}\right)$.

\begin{tabular}{|c|c|c|c|c|c|}
\hline \multirow{2}{*}{ Investigated feature } & \multicolumn{3}{|c|}{ Level of $\mathrm{AlCl}_{3}\left(\mathrm{mg}^{2} \cdot \mathrm{dm}^{3}\right)$} & \multirow{2}{*}{ LSD } \\
\cline { 2 - 5 } & 0 & 10 & 20 & 40 & P \\
\hline Hypocotyl diameter $(\mathrm{mm})$ & 1.57 & $1.35^{*}$ & $1.25^{*}$ & $1.10^{*}$ & 0.21 \\
\hline Thickness of primary cortex $(\mathrm{mm})$ & 0.39 & 0.36 & 0.33 & 0.35 & \\
\hline Diameter of central cylinder $(\mathrm{mm})$ & 1.18 & $0.99^{*}$ & $0.92^{*}$ & $0.75^{*}$ & 0.07 \\
\hline Thickness of outer epidermis cell walls $(\mu \mathrm{m})$ & 2.49 & 2.79 & $3.18^{*}$ & $3.36^{*}$ & 0.50 \\
\hline Height of outer epidermis cells $(\mu \mathrm{m})$ & 25.99 & 26.15 & 25.72 & 26.53 & \\
\hline Thickness of collenchyma layer $(\mu \mathrm{m})$ & 33.97 & 35.19 & 33.03 & 33.96 & \\
\hline Number of layers primary cortex parenchyma $(\mu \mathrm{m})$ & 5.16 & 5.30 & 5.33 & 5.50 & \\
\hline Thickness layer of primary cortex parenchyma $(\mu \mathrm{m})$ & 295.30 & 286.66 & 264.52 & 272.99 & \\
\hline Size of cortex parenchyma cells $(\mu \mathrm{m})$ & 57.38 & 56.32 & 49.79 & 49.86 & \\
\hline Length of cross section large vascular bundle $(\mu \mathrm{m})$ & 145.50 & $107.74^{*}$ & $108.90^{*}$ & $103.20^{*}$ & 20.27 \\
\hline Thickness layer of xylem in vascular bundle $(\mu \mathrm{m})$ & 83.00 & $67.91^{*}$ & $67.02 *$ & $66.35^{*}$ & 15.09 \\
\hline Diameter of maximum vessels $(\mu \mathrm{m})$ & 29.10 & 27.13 & $22.01^{*}$ & $21.20^{*}$ & 6.49 \\
\hline
\end{tabular}

Table 3

The influence of aluminum on number and size plastids of red pepper hypocotyl An asterix indicates a statistically significant difference from the control $\left(0 \mathrm{mg} \cdot \mathrm{dm}^{3} \mathrm{AlCl}_{3}\right)$.

\begin{tabular}{|c|c|c|c|c|c|c|c|}
\hline \multirow{2}{*}{\multicolumn{3}{|c|}{ Investigated feature }} & \multicolumn{4}{|c|}{ Level of $\mathrm{AlCl}_{3}\left(\mathrm{mg} \cdot \mathrm{dm}^{3}\right)$} & \multirow{2}{*}{$\begin{array}{l}\text { LSD } \\
\text { P } 0,05\end{array}$} \\
\hline & & & \multirow{2}{*}{$\begin{array}{c}0 \\
15.2\end{array}$} & \multirow{2}{*}{$\frac{10}{10.8}$} & \multirow{2}{*}{$\frac{20}{7.72}$} & \multirow{2}{*}{$\frac{40}{15.8}$} & \\
\hline Number of plastids in c & & Layer 1 & & & & & \\
\hline parenchyma cell & & Layer 4 & 14.2 & $8.1^{*}$ & 13.6 & $21.0^{*}$ & 3.83 \\
\hline \multirow{4}{*}{$\begin{array}{l}\text { Size of plastids in cortex } \\
\text { parenchyma cell }(\mu \mathrm{m})\end{array}$} & \multirow{2}{*}{$\begin{array}{l}\stackrel{\dot{\Xi}}{\Xi} \\
\stackrel{\Xi}{\beth}\end{array}$} & Lenght & 5.44 & 5.60 & 4.78 & 6.17 & \\
\hline & & Widht & 4.70 & 4.38 & 4.70 & 4.40 & \\
\hline & \multirow{2}{*}{$\frac{\grave{\Xi}}{\stackrel{\Xi}{\sigma}}$} & Lenght & 5.51 & 5.70 & $9.39 *$ & $10.68^{*}$ & 1.42 \\
\hline & & Widht & 4.72 & 4.27 & $9.03 *$ & $10.68^{*}$ & 1.34 \\
\hline \multicolumn{3}{|c|}{ Number of amyloplasts in endoderma cell } & 12.5 & 9.0 & 8.7 & 10.3 & \\
\hline \multirow{2}{*}{\multicolumn{2}{|c|}{ Size of amyloplasts $(\mu \mathrm{m})$}} & Lenght & 8.28 & 7.25 & $10.86^{*}$ & $11.04 *$ & 1.56 \\
\hline & & Widht & 7.70 & 6.45 & $10.32 *$ & $10.4 * 8$ & 1.49 \\
\hline
\end{tabular}



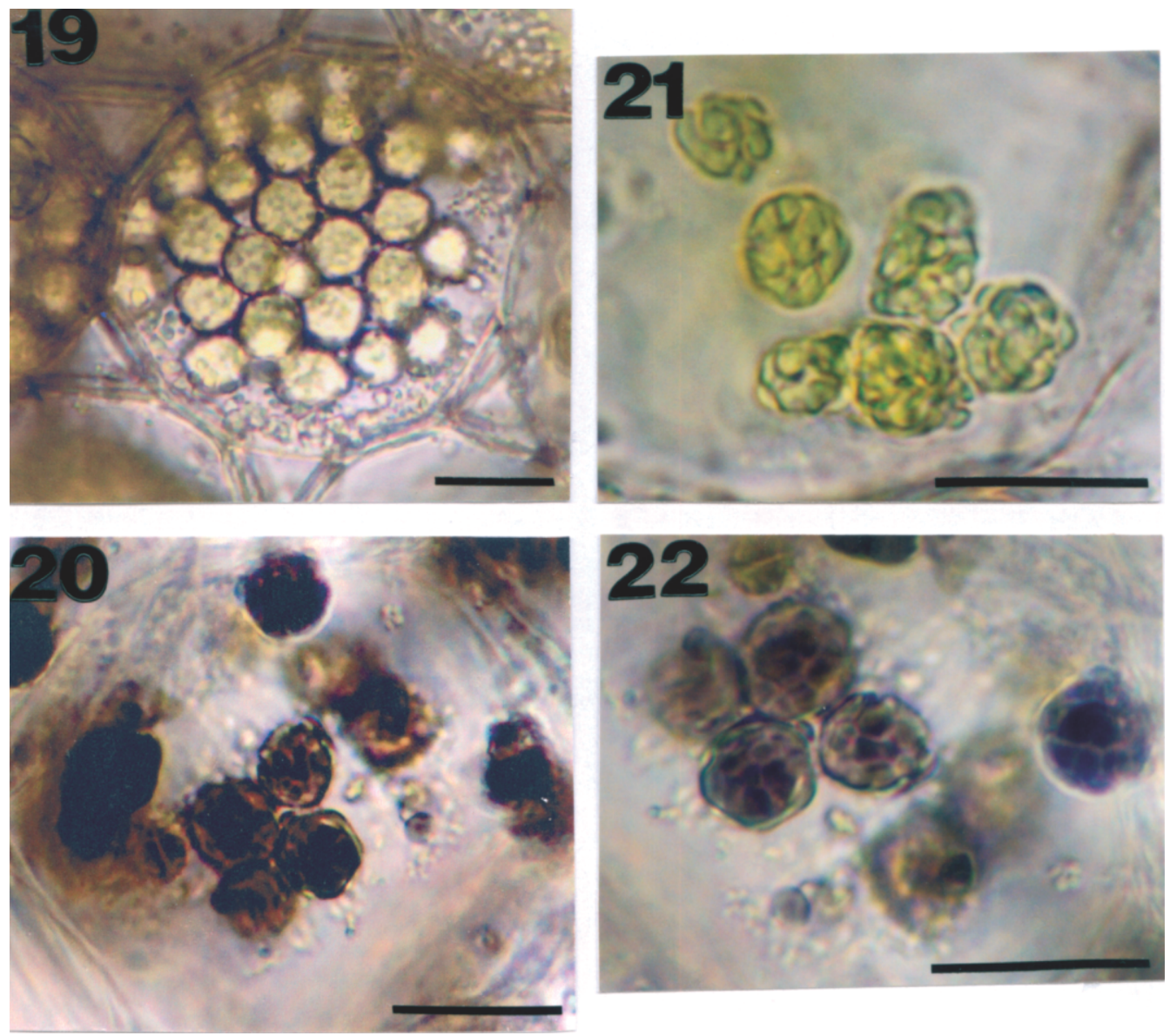

Figs. 19 22. Plastids in the fourth layer of red pepper hypocotyl parenchyma cortex after treatment $40 \mathrm{mg} \cdot \mathrm{dm}^{3} \mathrm{AlCl}_{3}$ : untreated (figs 19, 20) and treated Lugol's iodine solution (figs 21, 22). Bars $20 \mu \mathrm{m}$.

15). In many cells, dark, small bodies occurred (Figs. 14-16). Their presence was also noted in many cells of the next layers of parenchyma, both the cortex and pith of the hypocotyl (Figs. 11, 12, 14-16). All levels of aluminium contributed to a significant reduction of the height of the vascular bundle in the hypocotyl of the pepper seedlings (on the average, by $26 \%, 25 \%$ and $29 \%$ ) and a reduction of the xylem thickness in the vascular bundle, compared to the control object. At the same time, metaxylem vessels developed in the presence of aluminium were marked by a reduced clearance (Tab. 2, Figs. 17, 18). In the stems of the fourteen-day pepper seedlings, a significant increase in the number of plastids (by 48\%) was observed in the fourth parenchyma layer of primary cortex with the highest dose of aluminium (Tab. 3). And a significant increase in their size was noted at 20 and $40 \mathrm{mg} \cdot \mathrm{dm}^{-3}$ of $\mathrm{AlCl}_{3}$ in the fourth layer of this tissue, as well as in the endodermis (Tab. 3). In the presence of higher doses of aluminium, the occurrence of clusters of plastids was observed with clearly increased sizes in all cells of the parenchyma of the pepper hypocotyl, both of primary cortex and the central cylinder (Figs. 11, 12, 16, 18, 19, 21). These organelles contained very numerous, densely packed aggregates of reserve starch, intensively stained with dark-blue colour under the influence of Lugol's iodine solution (Figs. 20, 22). The bursting of the plastid membrane and the release of single starch grains were often observed.

\section{DISCUSSION}

In the conditions of aluminium stress, the growth and development of above-ground organs of red pepper were inhibited. The growth inhibition and the reduction of fresh weight of shoots under the influence of aluminium were found by researchers in other plant species (Larsen et al., 1997; Weryszko-Chmielewska et al., 1997; Kidd and Proctor, 2000). The reduced diameter of the hypocotyls was connected with a simultaneous reduction of the size of cells composing the tissues of this organ (epidermis, parenchyma, xylem vessels), what corresponds to results obtained by Jan hunen et al. (1995), Weryszko-Chmielewska et al. (1998) and Konarska (2005). The inhibition of growth of the pepper seedlings' shoots resulted not only from the deficient functioning of the root system, what 
had been earlier observed by the author of this paper (Konarska, 2004), but probably also from the disturbed, under the influence of aluminium, activity of important enzymes associated with the processes responsible for the proper growth, as well as photo synthesis and breathing (Lorenc-Plucińska and Ziegler, 1996; Lidon et al., 1999).

It is worth stressing that under the influence of aluminium the epidermis cells were characterised by thickened external walls, what could result from the formation of a thicker layer of the cuticle. As it is known, in many drought-resistant plants we find such a mechanism protecting the plant against excessive water loss (Kopcewicz and Lewak, 2005). It seems probable that in the conditions of aluminium stress, which is often accompanied by difficulties with water intake, the adaptation consisting in the development of thicker cuticular epithelium, enabling cuticular transpiration to be limited, reduces water loss. On the other hand, the increased thickness of the external cell wall of the epidermis could be caused by the accumulation of aluminium deposits in it. Garrec and Renard (1996) report the possibility of depositing compounds of this metal in the cuticular epithelium of the epidermis. The methodology used in this investigation does not allow the occurrence of aluminium deposits in the cuticle to be confirmed, whereas the presence of dark spherical bodies, which could probably be aluminium deposits, was observed in all cells of the organ examined, from the epidermis to the parenchyma of the pith. Such a deep penetration of ions of the toxicant confirms the previously determined, based on the tolerance index, very high sensitivity of red pepper to aluminium stress (K o n a r s k a , 2004). Light microscopy observations made in this investigation show that dark spherical formations are probably accumulated in vacuoles of the hypocotyl cells, what was not demonstrated by the studies of Shen and Ma (2001). These authors described in other plants the occurrence of aluminium deposits only in cell walls of the epidermis and parenchyma of leaves. But Carr et al. (2003) noted in leaves of tea, which is an aluminium-loving plant and so-called aluminium "accumulator", its deposits not only in cell walls of the epidermis, but also in its vacuoles, though their number was smaller there. It seems that at this stage of research it is necessary to continue observations by using electron microscopy, as well as $\mathrm{X}$ rays, what would allow both accumulation regions and the type of the toxicant's deposits in tissues of the pepper hypocotyl to be determined unequivocally.

The enlarged and more numerous plastids, filled with starch grains, noted in the investigation presented, may suggest a more difficult decomposition of this polysaccharide in chloroplasts (phosphorolysis). The above observations are confirmed by similar results obtained by Greger et al. (1992) and Schier and
McQuattie (1995) which explain the increased accumulation of starch by the limited availability of phosphate. The deficiency of this macroelement in the conditions of aluminium stress is also reported in studies of Janhunen et al. (1995) and Oleksyn et al. (1996).

The results obtained allow us to state that the disturbances observed in very toxicity-sensitive red pepper may be caused by the nutrient or water deficiency, but they also result from the toxic activity of ions of this metal.

\section{REFERENCES}

Bennet R. J., Steward A., 1999. The aluminum response network in perennial ryegrass (Lolium perenne): II. Water fluxes and ion transport. S. Afr. J. Plant Soil, 16(1): 19.

Borowski E., 1999. Wpływ dodatku do kultur piaskowych hydrożelu potasowego (Akrygelu K) lub zwiększonego nawożenia potasem na rośliny pomidora rosnące $\mathrm{w}$ obec ności zróżnicowanych dawek glinu. Część I. Reakcja ro ślin na glin i na dodatek hydrożelu potasowego. Annales UMCS, sect. EEE, 7: 101110.

Brauner L., Bunkatsh F., 1987. Praktikum z fizjologii ro ślin. PWN, Warszawa.

Budiková S., Mistrik I., 1999. Cultivar characterization of aluminum tolerance of barley seedlings by root growth, aluminum and callose distribution. Biol. Bratislava, 54, 447451.

Carr H. P., Lombi E., Kupper H., McGrath S.P., Wong M. H., 2003. Agronomie 23(8): 705710.

Garrec J. P., Renard E. 1996. Absorbtion foliaire de laluminum: etude de la fixation et de la penetration $\mathrm{cu}$ ticulaire. Envir. Exp. Bot. 36(4): 365375.

Greger M., Tillberg J.E., Johansson M., 1992. Alumi num effects on Scenedesmus obtusiusculus with differ ent phosphorus status. II. Growth, figssynthesis and $\mathrm{pH}$. Physiol. Plant. 84(2): 202208.

Janhunen S., Palomäki V., Holopainen T., 1995. Alu minum causes nutrient imbalance and structural chang es in the needles of Scots pine without inducing clear root injuries. Trees, 9: 134142.

Kidd P.S., Proctor J. 2000. Effects of aluminum on the growth and mineral composition of Betula pendula Roth. J. Exp. Bot. 51(347): 10571066.

Kopcewicz J., Lewak S. 1998. Podstawy fizjologii roślin. Wydawnictwo Naukowe PWN, Warszawa 1998.

Konarska A. 2004. Wpływ nadmiaru glinu na rozwój i budo wę korzeni trzech gatunków roślin. J. Elemental. 9(2):109 118.

Konarska A. 2005. Changes in the development and structure of Raphanus sativus L. var. radicula Pers. root under alu minium stress conditions. Acta Sci. Pol. Hortorum Cul tus, 4(1): 8597.

Larsen P. B., Kochian L.V., Howell S. H. 1997. Al inhibits both shoot development and root growth in als3, an Al sensitive Arabidopsis mutant. Plant Physiol. 114(4): 12071214. 
Lidon F. C., Barreiro M.G., Ramalho J.C., Lauriano J. A. 1999. Effects of aluminum toxicity on nutrient ac cumulation in maize shoots: implications on photo syn thesis. J. Plant Nutr. 22(2): 397416.

Lorenc Plucińska G., Ziegler H., 1996. Changes in ATP levels in Scot pine needles during aluminum stress. photo synthetica, 32(1): 141144.

Mangabeira P., Mushrifah I., Escaig F., Laffray D., Franca M. G., Galle P., 1999. Use of MISS micros copy and elektron probe $\mathrm{X}$ ray microanalysis to study the subcellural localization of aluminium in Vicia faba root cells. Cell Mol. Biol. 45(4): 413422.

Miller L.L., Jacks T. J. 1975. Rapid chemical dehydrata tion of samples for electron microscopy examinations. J. Histochem. Cytochem. 23:107.

Oleksyn J., Karolewski P., Gietrych M. J., Wer ner A., Tjoelker P., Reich B., 1996. Altered root growth and plant chemistry of Pinus silvestris seedlings subjected to aluminum in nutrient solution. Trees, 10(3): 135144.

Rufyikiri G., Dufey J.E., Nootens D., Delvaux B., 2001. Effect of aluminum on bananas (Musa sp.) cul tivated in acid solutions. II. Water and nutrient uptake. Fruits Paris, 56(1): 516.

Schier G. A., McQuattie C. J., 1995. Effect of aluminum on the growth, anatomy, and nutrient content of ectomy corrhizal and nonmycorrhizal eastern white pine seed lings. Can. J. For. Res. 25: 12521262

Shen R., Ma J. F. 2001. Distribution and mobility of aluminum in an $\mathrm{Al}$ accumulating plant, Fagopyrum esculentum Moench. J. Exp. Bot. 52(361): 16831687.
Weryszko Chmielewska E., Chwil M., Szadura M., 1998. Wpływ nadmiaru glinu na budowę łodygi i liści grochu zwyczajnego (Pisum sativum L.). Zesz. Probl. Post. Roln. 456: 623 628.

Weryszko Chmielewska E., Konarska A., Badora A., Filipek T., 1997. Zmiany morfologiczne i anatomiczne w organach roślin zbożowych uprawianych na glebach silnie zakwaszonych. Annales UMCS, sect. EEE, 5: 255 266

\section{Zmiany w budowie pędów siewek papryki rocznej pod wpływem glinu}

\section{Streszczenie}

Siewki Capsicum annuum 'Trapez' przez 14 dni uprawiano w kulturach wodnych zawierających: 0,10 , 20 i $40 \mathrm{mg} \mathrm{AlCl}_{3} \cdot 6 \mathrm{H}_{2} \mathrm{O} \mathrm{w} \mathrm{dm}^{-3}$ pożywki i analizowano ich łodygi pod względem występowania zmian morfologiczno-anatomicznych. W obecności glinu zaobserwowano redukcję wysokości łodygi oraz jej średnicy, jak również zmniejszenie świeżej masy pędu. Miękisz kory pierwotnej w kolejnych dawkach glinu tworzył w hypokotylu cieńszy pokład. Stwierdzono zmniejszenie wielkości komórek budujących poszczególne tkanki hypokotylu oraz wzrost grubości zewnętrznych ścian komórek epidermy. Po traktowaniu Al w komórkach miękiszu hypokotylu (kory pierwotnej oraz walca osiowego) występowały liczne plastydy o powiększonych rozmiarach, zawierające ziarna skrobi zapasowej, jak również drobne, ciemne ciałka będące prawdopodobnie depozytami glinu, czego nie stwierdzono u roślin kontrolnych. 
